\title{
PROBABILITY OF STROKE IN THE COUPLES OF STROKE PATIENTS; USING FRAMINGHAM STROKE RISK PROFILE
}

\author{
Taşkın DUMAN, Esra E. OKUYUCU, İsmet M. MELEK, Serkan YILMAZER, \\ Tacettin İNANDI, Necdet MENGÜLLÜOĞLU
}

\author{
Mustafa Kemal Üniversitesi Tıp Fakültesi Nöroloji Anabilim Dalı, ANTAKYA
}

\begin{abstract}
INTRODUCTION: Environmental and personal factors may be of importance for stroke risk. We determined the stroke risk factors among the stroke patients' couples and controls.

MATERIAL AND METHODS: A prospective study was conducted on 221 participants (71 stroke patients, 71 stroke patients' couples, 79 controls) aged more than 54 years. Framingham Stroke Risk Profile was used to measure the stroke risk.

RESULTS: In subjects aged 54 years and older, became a couple of stroke patient were not associated with an increased risk of stroke.

CONCLUSION: In this study, environmental and personal factors were an independent risk factor for stroke in stroke patients' couples and controls older than 54 years.

Key Words: Stroke, Couples, Framingham.
\end{abstract}

\section{STROK HASTALARININ EŞLERINDE FRAMINGAM STROK RISKK PROFILINE GÖRE STROK GEÇIRME OLASILIĞI}

ÖZET

GíRIŞ: Çevresel ve kişisel faktörler Strok riskinde etkili olabilir. Biz strok hastalarında, eşlerinde ve kontrol grubunda strok risk faktörlerini inceledik.

GEREÇ VE YÖNTEM: 54 yaş ve üzerindeki 221 katılımcıya ( 71 strok hastası, 71 strok hastası eşi ve 79 kontrol grubu) strok riskini belirlemek için Framingam Strok risk skalası uygulandı.

BULGULAR: 54 yaş ve üzerindeki strok hastası eşlerinde strok riskinde artış saptanmadı.

SONUÇ: Bu çalıșmada, çevresel ve kișisel faktörler 54 yaș ve üzerindeki strok hasta eșleri ve kontrol grubunda bağımsız bir risk faktörüdür.

Anahtar Sözcükler: Strok, Eş, Framingam.

\section{INTRODUCTION}

Stroke becomes a growing healthcare problem in terms of disease burden, economic and social implications (1). Although many risk factors for stroke have been known, there are insufficient data on the genetic and environmental factors (2). Both twin, family studies and animal models support a role for genetic factors in stroke risk $(2,3)$. But, candidate gene studies had inconsistent and inconclusive results because of the heterogeneity of pathophysiological mechanisms causing stroke. It has been suggested that familial factors have been important in individuals presenting with stroke at younger ages and in some stroke types $(3,4)$. Little is known about environmental factors on the incidence of stroke. Although there are welldocumented modifiable risk factors of stroke, there is a broad category of environmental factors for stroke such as latitude, season, temperature (5), environmental tobacco smoke (6), radiation $(7,8)$, metals (9), air pollution (10), drinking water parameters (11), pesticides (12). And also the psychosocial environment might be associated with 
increased risk of cerebrovascular disease. As usual there 's problem about inability to compare the datas among different peoples and areas. Because there isn't any standardized methods and diagnostic criteria for these environmental factors causing cerebrovascular disease.

In this study, we're interested to investigate environmental influences on the stroke risk. Using a same environment (where nearly almost all environmental influences welding) by choosing couples as a marker of stroke risk, we tried to determine the effect of environmental factors on stroke risk, specially focusing on stroke patients' husband or wifes that are likely to have the most similiar environmental component and to determine the risc profile of stroke patients' couples by using Framingham Stroke Risk Profile, a risk assesment tool for stroke incidence (13).

\section{MATERIAL AND METHODS}

The patients were collected from the stroke outpatient clinic of Mustafa Kemal University Hospital Neurology Department. 71 patients aged more than 54 with a diagnosis of stroke and their couples were recruited. Control subjects with the same gender and age were randomly chosen from the general neurology outpatient clinic. We identified 79 control subjects matching couples of patients with stroke. The local Ethics Committee approved the study.

All cases were examined by a neurologist and underwent neuroimaging (CT and/or MRI) and an ECG. All patients had extracranial carotid and vertebral duplex ultrasound. Among all participants, information on demographic characteristics, modifiable risk factors and environmental risk factors (including temperature, seasonal changes, economic, social and/or physical environments, environmental tobacco smoke, avoiding irritants, radiation, air pollution, drinking water parameters, psychosocial environments) were collected using a structured questionnaire. Cerebrovascular risk factors scores were determined using Framingham Stroke Risk Profile, a risk assessment tool used to assess the 10-year stroke incidence (13). Stroke risk factors included age, systolic blood pressure, use of antihypertensive therapy, diabetes mellitus, previously diagnosed cardiovascular disease (coronary heart disease [ includes history of myocardial infarction, angina pectoris, and coronary insufficiency], cardiac failure, and intermittent claudication), cigarette smoking, atrial fibrilation, and left ventricular hypertrophy by electrocardiogram (13). Points taken from the scale were recorded for each couple and control.

\section{Statistical Analysis}

Demographic properties of patients were summarized by descriptive statics. Mann-Whitney $\mathrm{U}$ - test was conducted. Two-sample t test were used for analysing continous variables . Calculation were made using SPSS (version 11.5).

\section{RESULTS}

The gender distribution for the cases, cases' couples and controls was 120 women ( 18 cases, 53 cases' couples and 49 controls) and 101 men ( 53 cases, 18 cases' couples and 30 controls); the mean \pm SD ages were $67.78 \pm 7.74$ years for cases and $63.30 \pm 8.6$ years for couples and controls. There were no significant differences between age of cases' couples and controls with regard to age and sex in the overall analysis. There were a significant difference between number of men and women stroke patients in the study $(\mathrm{p}<0.05)$. Diabetes mellitus, heart disease, systolic blood pressure, antihypertansive treatment, atrial fibrillation, and current smoking were not significantly different in cases' couples than in control except for systolic blood pressure and left ventricular hypertrophy. Probable risk factor profiles of stroke patients, couples and controls are given in Table I and II.

Table I: Statistics for Significant Risk Factors in Stroke Patients

\begin{tabular}{|ll|}
\hline Total, $\mathrm{n}$ & 71 \\
& \\
Antihypertansive therapy (\%) & $140.4 \pm 22.8$ \\
Diabetes Mellitus, $\mathrm{n}(\%)$ & $48(67.6 \%)$ \\
KKY, $\mathrm{n}(\%)$ & $35(49.3 \%)$ \\
Atrial Fibrillation & $4(5.6 \%)$ \\
Left ventricule hypertrophy & $15(21.1 \%)$ \\
Smoking & $14(19.7 \%)$ \\
& $13 \pm 5.3$ \\
\hline${ }^{*}$ Age , SBP (systolic blood pressure), and average points are given as year \pm
\end{tabular}

$\mathrm{SE}$, and mean $\pm \mathrm{SE}$.

The mean levels of points taken from the Framingham Stroke Scale for determining the stroke profiles of couples and controls were similiar in men and women ( $p>0.05)$. 
Table II: Summary Statistics for Significant Risk Factors in Stroke Patients' Couples and Controls and Correlation Between Them

\begin{tabular}{|c|c|c|c|c|c|}
\hline & \multicolumn{2}{|l|}{ Control } & \multirow[t]{2}{*}{$p$ value } \\
\hline Total, $\mathrm{n}$ & 71 & & \multicolumn{2}{|l|}{79} & \\
\hline $\begin{array}{l}\text { Mean age, } y \\
\text { (SE) }\end{array}$ & \multicolumn{2}{|c|}{$63.7 \pm 8.5$} & $62.8 \pm 8.7$ & & 0.42 \\
\hline $\begin{array}{l}\text { Systolic Blood } \\
\text { Volume, v (SE) }\end{array}$ & \multicolumn{2}{|c|}{$138.7 \pm 18.5$} & \multicolumn{2}{|c|}{$129.6 \pm 17.2$} & $0.002+$ \\
\hline $\begin{array}{l}\text { Antihypertansiv } \\
\text { e therapy, n, \% }\end{array}$ & 18 & $25.4 \%$ & 33 & $41.8 \%$ & 0.035 \\
\hline $\begin{array}{l}\text { Diabetes } \\
\text { Mellitus, n, (\%) }\end{array}$ & 8 & & 13 & $11.3 \%$ & 0.126 \\
\hline CVD, n, (\%) & 3 & $4.2 \%$ & 2 & $2.5 \%$ & 0.565 \\
\hline $\begin{array}{l}\text { Atrial } \\
\text { Fibrillation, n, \% }\end{array}$ & 1 & $1.4 \%$ & 5 & $6.3 \%$ & 0.126 \\
\hline $\begin{array}{l}\text { Left ventricule } \\
\text { hypertrophy, n, } \\
\%\end{array}$ & 3 & $4.2 \%$ & 11 & & $0.042+$ \\
\hline $\begin{array}{l}\text { Smoking, n, \% } \\
\text { Average points }\end{array}$ & 14 & $19.7 \%$ & 11 & $13.9 \%$ & 0.343 \\
\hline $\begin{array}{l}\text { from } \\
\text { Framingham } \\
\text { Scale }\end{array}$ & $8.1 \pm 4.4$ & & $8.5 \pm 5.9$ & & 0.889 \\
\hline
\end{tabular}

The average 10-year probability of stroke points were similiar in men and women, and also in stroke patients' couples and controls ( $\mathrm{p}>0.05)$.

The probability of stroke in an individual depends on the presence and levels of risk factors. The average 10-year probability of stroke can be calculated by using Framingham stroke scale. In our study the average point for the stroke patients, their couples and controls was $13.0 \pm 5.3,8.1 \pm 4.4$, and $8.5 \pm 5.9$. There was no significant difference between the probability of stroke between couples and controls $(p>0.05)$.

\section{DISCUSSION}

Stroke is one of the important causes of mortality and morbidity worldwide (14). It will continue to increase as the population ages and case-fatality decreases with better emergency care. It is therefore of general interest to analyse risk factors for stroke which could be prevented through interventions. The main treatable risk factors for stroke were identified as hypertension, diabetes mellitus, dyslipidemia, atrial fibrillation, carotid stenosis, cigarette smoking. A study of cardiac and stroke deaths in New Zeland determined that the main vascular risks were the result of social conducts [diet (30\%), smoking
(18\%), sedentary life style (10\%)]. Less frequent risk factors were hypercholesterolemia (17\%), hypertension $(15 \%)$, obesity $(12 \%)$, infection $(6.5 \%)$, air pollution $(6 \%)$ and occupation $(3.5 \%)$ (15). Pharmacological therapies, including lipidlowering and anti-hypertensive medications, are efficacious in lowering some of the risk factors, the overall reduction risk is relatively modest and could be greatly improved by the addition of life style modifications.Stamler et al found that a lowrisk life style, defined as cholesterol $<200 \mathrm{mg} / \mathrm{dL}$, blood pressure $<120 / 80 \mathrm{mmHg}$, and not smoking, was associated with $52 \%$ to $76 \%$ lower risk of total sroke mortality (16).

There isn't enough knowledge about environmental influences on the incidense of stroke among the population. There's also limited evidence of peoples' knowledge about the ability to reduce their risk of stroke by changing environmental effects.

The lack of standardized methods and diagnostic criteria, the assessment of exposure of environmental factors those were thought to influence stroke and the impossibility to compare these findings to other population remain a big problem and cause confusion. For example; although some studies mentioned that the incidence and/or mortality of stroke were highest in winter through colder months $(17,18)$, several reported that ischemic stroke incidence peaks in winter -spring months (19). Some authors also reported that improvement of in home heating might cause decline in stroke incidence (20). Some authors didn't find any seasonal variation or relation between stroke rates and temperature (21).

Epidemiologic study has shown key risk factors for stroke and provided an estimate of the relative impact of these risk factors (13). A health risk appraisal function has been found for the prediction of stroke by using the Framingham Study cohort. The stroke risk factors included in the profile are age ( $>54$ year), systolic blood pressure, the use of antihypertensive therapy, diabetes mellitus,cigarette smoking, prior cardiovascular disease (coronary heart disease, cardiac failure, intermittent claudication), atrial fibrillation, and left ventricular hyperthrophy by electrocardiogram (13). In Framingham study, there isn't any discrimination as a risc profile for ischemic an/or hemorragic stroke. By using this simple profile, stroke risk can be estimated easily.

Turkish Journal of Cerebrovascular Diseases 2012 18:2; 35-38 
In this study, we used Framingham stroke scale and don't distinguish the risk factors for ischemic an/or hemorragic stroke as in the original study.

A lot of article and text books mentioned that male sex may be a stronger risk factor for stroke. The incidence is about 30\% higher in men than in women. In our study, male patient number is also higher than women patient similiar to references.

In our study, only systolic blood pressure ( higher in couples group) and left ventricular hypertrophy (more in control group) were found significantly different in couples and controls. The other parameters were not significantly different. The reason of difference can due to only personel specialties or incidental. Because there isn't any difference between the other whole parameters.

The limititation of this study is not to use transcranial doppler USG besides extracranial carotis USG.The reason of this limitation is not to have a transcranial USG in our hospital.

At present, results of our investigation indicate that environmental factor is an independent factor for stroke. We didn't find a significant correlation between the average 10year stroke probability points of couples and controls $\quad(p>0.05)$. And there wasn't any significance difference between the points of women and men both in couples and controls (Table III).

Table III: The distribution of points taken from Framingham Stroke Scale (FSS) according to sexuality

\begin{tabular}{|c|c|c|c|}
\hline & $\begin{array}{c}\text { Couples of stroke } \\
\text { patients }\end{array}$ & \multicolumn{2}{|c|}{ Controls } \\
\hline & Women (n) Men (n) & Women (n) & Men (n) \\
\hline FSS & $7.34 \pm 4.4$ & $7.73 \pm 5.54$ & $9.83 \pm 6.40$ \\
\hline$p$ value & 0.09 & 0,128 & \\
\hline
\end{tabular}

In this present, datas we gain suggests that variation of environmental factors at patients with high risk for cerebrovascular diseases act as synchronizers to influence stroke.

So personal behaviours became more important for individuals while calculating the 10year stroke probability profile. Even sharing some part of life, environment and maybe some behaviours with stroke patients, don't mean that the couples of them have the same risks for the vascular disease especially for stroke.

Türk Beyin Damar Hastalıkları Dergisi 2012 18:2; 35-38

\section{KAYNAKLAR}

1. Kjeljdsen S.E, Julıus S, Hedner T. et al. Stroke is more common than myocardial infarction in hypertension: analysis based on 11 major randomized intervention trials. Blood Pressure 2001;10: 190-192.

2. Flossmann E, Schulz U.G, Rothwell P.M. Systematic review of methods and results of the genetic epidemiology of ischemic stroke. Stroke 2004;35: 212-227.

3. Hassan A, Markus H.S. Genetics and ischemic stroke. Brain 2000;123: 1784-1812.

4. Jousilahti P, Rastenyte D, Tuomılehto J. et al. Parental history of cardiovascular disease and risk of stroke: a prospective follow-up of 14371 middle-aged men and women in Finland. Stroke 1997;28: 1361-1366.

5. Feigin VL, Wiebers DO. Environmental Factors and Stroke: A Selective Review.Journal of Stroke and Cerebrovascular Diseases 1997; 6 (3): 108-113.

6. Bonita R, Duncan J, Truelsen T, Jackson RT, Bbeaglehole R. Passive smoking as well as active smoking increases the risk of acute stroke. Tob Control 1999; 8:156-160.

7. Kearshley JH. Late cerebrovascular disease after radiation therapy-report of two cases and a review of literature. Australas Radiol 1983;27:11-18.

8. Loftus CM, Biller J, Hart MN, Correll SH, Hiratzka LF. Management of radiation-induced arteriosclerosis. Arch Neurol 1987;44:711-714.

9. Salonen JT, Seppanen K, Nyyssonen K, et al. Intake of mercury from fish, lipid peroxidation, and the risk of myocardial infarction and coronary, cardiovascular, and any death in eastern Finnish men. Circulation 1995,91:645-655.

10. Maheswaran R, Elliott P. Stroke mortality associated with living near main roads in England and wales: a geographical study. Stroke 2003, 34:2776-2780.

11. Mulcahy R. The influence of water hardness and rainfall on the incidence of cardiovascular and cerebrovascular mortality in Ireland. J Irish Med Assoc 1964;55:17-18.

12. Cantor KP, Silberman W: Mortality among aerial pesticide applicators and flight instructors: follow-up from 1965-1988.Am J Ind Med 1999, 36:239-247.

13. Wolf P.A., D'agostino R., Belanger A.J. et al. Probability of stroke: a risk profile from the Framingham Study. Stroke 1991;22: 312-318.

14. Feigin V.L, Lawes C.M, Bennett D.A et al.Stroke epidemiology: a review of population-based studies of incidence, prevalance, and case-fatality in the late 20th century. Lancet Neuro., 2003, 2:43-53.

15. Tobias M, Turley M. Causes of death classified by risk and condition. Aust N Z J Public Health 2005;29: 5-12.

16. Stamler J., Stamler R., Neaton J.D. et al. Low risk- factor profile and long-term cardiovascular and noncardiovascular mortality and life expectancy: findings for 5 large cohorts of young adult and middle-aged men and women. JAMA 1999;1:282 (21): 2012-2018.

17. Shinkawa A, Ueda K,Hasuo Y,Kiyohara Y, Fujshima M, Seasonal variation in stroke insidence in Hisayamaa, Japan. Stroke 1990;21:1262-1267.

18. Bokonjic R, Zec N. Stroke and the weather. A quantative statistical study. J Neurol Sci 1968;6;483-491.

19. Sobel E, Zhang Z-X, Alter $M$, et al. Stroke in Leigh valley:seasonal variation in incidence rates. Stroke 1987;18:38.

20. Gill JS, davies P, Beevers DG. Wind-chill and the seasonal variation of cerebrovascular disease. J Clin Epidemiol 1988;41:225-230.

21. Olivares L, Castaneda E, Giffe A, Alter M. Risk factors in stroke: a clinical study in Mexican patients. Stroke 1973;4 (5):773-81. 